\title{
Quantification of CD4+ CD25+ Regulatory T Cells in Peripheral Blood of Patients with Systemic Lupus Erythematosus and Rheumatoid Arthritis
}

\author{
Ahmed Al-Shukaili ${ }^{1, *}$, Juma AlKaabi ${ }^{2}$, Saif Al-Gafri ${ }^{1}$, Batool Hassan ${ }^{2}$ and Abdullah Al-Muneeri ${ }^{3}$ \\ ${ }^{I}$ Department of Microbiology and Immunology; ${ }^{2}$ Department of Medicine and ${ }^{3}$ Departments of Epidemiology and Statis- \\ tics, College of Medicine and Health Sciences, Sultan Qaboos University, P.O. Box 35, PC 123, Muscat, Sultanate of \\ Oman
}

\begin{abstract}
Recent animal studies have shown that regulatory T cells play a crucial role in the suppression of the immune response and that depletion of this subset of $T$ cells might lead to development of autoimmune diseases. The aim of this work was to quantify regulatory T cells (CD4+ CD25+) in the peripheral blood of Omani patients with Systemic Lupus Erythematosus (SLE) and Rheumatoid arthritis (RA) and correlate these findings with the disease activity of the patients. Thirty patients with SLE, 30 patients with RA and 25 healthy volunteers were enrolled in this study. Patients were divided into highly active or low active groups, depending on the disease activity. Flow cytometer was used to quantify CD4+ CD25+ T cells in the peripheral blood mononuclear cells (PBMC). We found that both highly active SLE $(0.242 \pm 0.3)$ and RA $(0.56 \pm 0.29)$ patients had significantly $(\mathrm{p}<0.001)$ lower levels of CD4+CD25 $5^{\text {bright }} \mathrm{T}$ cells than did normal controls $(1.74 \pm 0.47 \%)$ or patients with low disease activity ( $\mathrm{SLE}=1.54 \pm 0.33, \mathrm{RA}=1.829 \pm 0.76)$. The decreased number of $\mathrm{CD} 4+\mathrm{CD} 25^{\text {bright }} \mathrm{T}$ cells during disease activity was restored in remitting phase of SLE patients. This data provides further evidence supporting the hypothesis of defect of regulatory T cells in SLE and RA patients; which may have an important implication in the context of the control of the inflammation and development of autoimmunity.
\end{abstract}

Key Words: CD25, Regulatory T cells, SLE, RA.

\section{INTRODUCTION}

The main function of the immune system is to protect the individual from pathogens and one of its primary characters is the ability to distinguish between self and non-self and between antigens encountered in harmful and non-harmful manner. In the thymus, potentially self-reactive $\mathrm{T}$ cells are deleted, resulting in the generation of a peripheral T-cell repertoire that is largely self-tolerant. Despite this, some selfreactive $\mathrm{T}$ cells are present in most individuals. Nevertheless, autoimmune diseases only occur occasionally, which suggests that autoreactive $\mathrm{T}$ cells are controlled in the periphery $[1,2]$.

Systemic Lupus Erythematosus (SLE) is a chronic systemic autoimmune disease. Like other related illnesses its etiology is still unknown. Multiple defects in the immune system of patients with this condition have been described; these include B cells over activity, defects in lymphoid activation process, and aberrant cytokine production $[3,4]$.

Rheumatoid arthritis (RA) is a systemic inflammatory disease, characterized by chronic synovial inflammation resulting in cartilage and bone damage, eventually leading to joint destruction [5]. Several different cell types and their mediators are involved in the tissue-destructive inflammation, e.g., $\mathrm{T}$ cells, B cells, monocyte/macrophages, and pro-

*Address correspondence to this author at the Department of Microbiology and Immunology, College of Medicine \& Health Sciences, Sultan Qaboos University, P.O. Box 35, PC 123, Muscat, Sultanate of Oman; Tel: (968) 2414 3472; Fax: (968) 2441 3419; E-mails: shukaily @ squ.edu.om; ashukaily@hotmail.com inflammatory cytokines such as tumor necrosis factor (TNF) and interleukin-1 (IL-1) [5-7]. The fact that the inflammatory process in RA is chronic suggests that immune regulation in the joint is disturbed. This disturbed regulation may be caused by an excessive inflammatory response together with a deficiency in the mechanisms that control the immune response [5].

In 1995 Sakaguchi and colleagues showed that a minor population (approximately 5-10\%) of CD4+ T cells was crucial for control of autoreactive T cells in vivo. These cells coexpressed the Interleukin-2 (IL-2) receptor $\alpha$ chain (CD25) and CD4, thus named CD4+ CD25+ T cells or CD25+Treg (regulatory $\mathrm{T}$ cells) [8]. Subsequent in vitro studies by several groups confirmed that $\mathrm{CD} 4+\mathrm{CD} 25+\mathrm{T}$ cells play a crucial role in suppression of the immune response [9-11].

The mechanisms used by regulatory $\mathrm{T}$ cells to suppress immune response are still unresolved. However, a number of hypotheses have been suggested: these cells can kill autoreactive cells by several mechanisms including: inactivate APC or T cells via CTLA-4 and release or express molecules (such as perforin and TGF- $\beta$ ) to suppress auto-reactive cells $[2,12,13]$.

Several studies of CD4+CD25+ $\mathrm{T}$ cells have been conducted in SLE patients, presenting conflicting results. A recent study done by Azab et al. showed that the levels of CD4+CD25+ \% T cells in SLE patients were higher than in the control group, but it was statistically insignificant [14]. Also Suárez et al. [15] found no significant difference of $\mathrm{CD} 4+\mathrm{CD} 25+\% \mathrm{~T}$ cells between SLE patients and control 
group. On the other hand, several studies reported a decrease in the percentage of CD4+CD25+ $\mathrm{T}$ cells in SLE patients $[16,17]$.

Similarly discrepant data were reported in RA patients; Lawson et al. reported deficit in CD4+CD25 $5^{\text {bright }}$ regulatory cells in peripheral blood of early active RA compared to patients with reactive arthritis or control group [18]. However, Minami et al. reported that the percentage of CD4+CD25+ T cells was higher in RA patients than controls, but it was not statistically significant [19]. Other reports showed increased number of these cells in RA synovial fluid but not in peripheral blood [20-22].

Studies of regulatory $\mathrm{T}$ cells are limited in the middle east and no study has been conducted in the gulf states. The aim of this work was to quantify the CD4+CD25+ T cells mainly CD4+CD25 ${ }^{\text {bright }} \mathrm{T}$ cells in Omani Arab patients with SLE and RA during diseases activity and remission periods.

\section{SUBJECTS AND METHODS}

Subjects: Thirty patients ( 25 females and 5 males, mean age $44 \pm 16$ ) with SLE, 30 patients with RA ( 25 females and 5 males, age $45 \pm 15$ ), and 25 healthy volunteers (20 female and 5 male, mean age $35 \pm 7$ ) were enrolled in this study. Patients attended the Rheumatology Clinic at Sultan Qaboos University Hospital (SQUH), and all receiving immunosuppressive drugs. The patients fulfilled the American College of Rheumatology (ACR) criteria for SLE [23] or RA [24]. Diseases activity for SLE was assessed using an SLE disease activities index (SLEDAI) [25] and the disease activity for RA was determined using DAS score [26].

Both SLE and RA patients were divided into two groups; a group with low activity of the disease and another group with highly active disease. The SLEDAI score for low active SLE patients was between $0-8$ points; whereas, for the highly active SLE patients were above 8 points. Similarly, low active RA must have a DAS score less than 2.6; whereas, highly active RA patients must have DAS score of equal or above 5.4 points. Demographic information and disease manifestations of SLE and RA patients were shown in Tables 1 and 2 respectively.

Informed consent was obtained from each subject. The Study was approved by the Medical Research and Ethics Committee (MREC) at the College of Medicine, Sultan Qaboos University (SQU).

\section{Peripheral Blood Mononuclear Cell (PBMC) Preparation}

Peripheral venous blood was drawn from each subject in heparin-containing vacutainer tubes. PBMC were isolated by density centrifugation on Ficoll-Hypaque (Sigma, USA) Buffy coats were harvested, cells were washed (centrifuged at $300 \mathrm{~g}$ for 5 minutes) in Hanks balanced salt solution (HBSS), (GIBCO, Paisley, UK) and maintained in RPMI1640 (GIBCO) medium supplemented with $10 \%$ heatinactivated fetal calf serum (FCS, Sigma), 2mM L-glutamine, 100 units $/ \mathrm{ml}$ penicillin and $100 \mu \mathrm{g} / \mathrm{ml}$ streptomycin. This medium will be defined as complete medium.

\section{Phenotype Analysis}

CD4+ CD25+ T cells were measured by flow cytometry (FacsCaliber, Becton Dickinson USA) method, as described previously $[16,17]$ with minor modification. Briefly PBMC were adjusted to $4-5 \times 10^{6} \mathrm{cell} / \mathrm{ml}$. One hundred $\mu \mathrm{l}$ of cell suspension was simultaneously incubated with $20 \mu \mathrm{l}$ of peridinin chlorophyll protein (PerCP)-conjugated anti-CD3, flourescein isothiocynate (FITC)-conjugated anti-CD4, and Phycoerythrin (PE)-conjugated anti-CD25 (Becton Dickson, San Jose CA, USA) in the fridge (at $2-8{ }^{\circ} \mathrm{C}$ ) for 30 minutes. Cells incubated with FITC and PE-conjugated mouse IgG were used as isotype control. Ten thousands events were collected, and CD3+ cells were selected and gated for CD4 and CD25 expression. Analysis was performed on a FacsCaliber flow cytometer using CellQuest software (Becton Dickinson). Results are expressed as the percentages of cells of the total population.

Table 1. Demographic Information and Disease Manifestations of SLE Patients

\begin{tabular}{|l|c|}
\hline \multicolumn{1}{|c|}{ Total SLE Patients } & N=30 \\
\hline \hline Female/Male & $25 / 5$ \\
Age (mean \pm SD) & $44 \pm 16$ \\
Clinical manifestation, n (\%) & \\
Skin (malar rash, vasculitis, discoid lupus) & $10(33 \%)$ \\
Renal & $22(73 \%)$ \\
Neurological & $8(27 \%)$ \\
Cardiac & $5(22.7 \%)$ \\
Respiratory & $10(33 \%)$ \\
Haematological & $22(73 \%)$ \\
SLEDAI score & \\
Range & $0-30$ \\
Mean \pm SD & $15 \pm 12$ \\
\hline
\end{tabular}

Table 2. Demographic Information and Disease Manifestations of RA Patients

\begin{tabular}{|l|c|}
\hline \multicolumn{1}{|c|}{ Total RA Patients } & N=30 \\
\hline \hline Female/male & $25 / 5$ \\
Age (mean \pm SD) & $45 \pm 15$ \\
Clinical manifestation & \\
Erosions, n (\%) & $22(73 \%)$ \\
Extra-articular feature $\mathrm{n}(\%)$ & \\
Nodules & $10(33 \%)$ \\
Vasculitis & $1(3 \%)$ \\
Neuropathy & $1(3 \%)$ \\
Other & $3(10 \%)$ \\
DAS score & \\
Range & $0-8$ \\
Mean & 4.7 \\
\hline
\end{tabular}

\section{Statistical Analysis}

SPSS software program was used for the data analysis; Descriptive values of variable were expressed as the mean \pm SD. All variables were normally distributed and analyzed by 
student t-test. $\mathrm{P}$ value less than 0.05 was considered statistically significant.

\section{RESULTS}

As shown in Fig. (1), there is a variation in the percentages of CD4+CD25+ $\mathrm{T}$ cells, in both normal controls and patients with SLE or RA. The mean percentages of total CD4+CD25+ T cells were lower in low active SLE (10.50 \pm $5.99)$, highly active SLE $(9.9 \pm 2.13)$ and highly active RA $(10.42 \pm 2)$ patients, compared to healthy control (12.93 \pm $5.8)$, but statistically insignificant. Whereas the mean percentages of CD4+CD25+ $\mathrm{T}$ cells in low active RA group $(15.48 \pm 5.74)$ were slightly higher than controls.

If we defined those CD4+CD25+ T cells with fluorescence intensity of CD25 expression exceeding 100 as CD4+ $\mathrm{CD} 25^{\text {bright }} \mathrm{T}$ cells, as previously described [17], we found that both highly active SLE $(0.242 \pm 0.3)$ and RA $(0.56 \pm$ $0.29)$ patients had significantly $(\mathrm{p}<0.001)$ lower levels of
CD4+CD25 ${ }^{\text {bright }} \mathrm{T}$ cells than normal controls $(1.74 \pm 0.47 \%)$ or the groups with low activity $(\mathrm{SLE}=1.54 \pm 0.33, \mathrm{RA}=1.829$ \pm 0.76 ). low active SLE group had also decreased levels of CD4+CD25 $5^{\text {bright }} \mathrm{T}$ cells compared to normal controls; but did not reach a statistical significance (Fig. 2).

$\mathrm{CD} 4+\mathrm{CD} 25^{\text {bright }}$ regulatory $\mathrm{T}$ cells were measured in seven patients with highly active SLE and measured again after 3-8 months when patients were in remission period; we found that the decreased number of CD4+CD25 $5^{\text {bright }} \mathrm{T}$ cells was restored in remitting phase (Fig. 3).

\section{DISCUSSION}

In the present study, we have reported that highly active SLE or RA (but not patients with low activity) patients exhibited significantly low level CD4+CD25 $5^{\text {bright }}$ regulatory $\mathrm{T}$ cells compared to healthy controls. This is in agreement with previous studies done by several other investigators, enrolling different ethnic groups of patients $[16,17]$. Low active

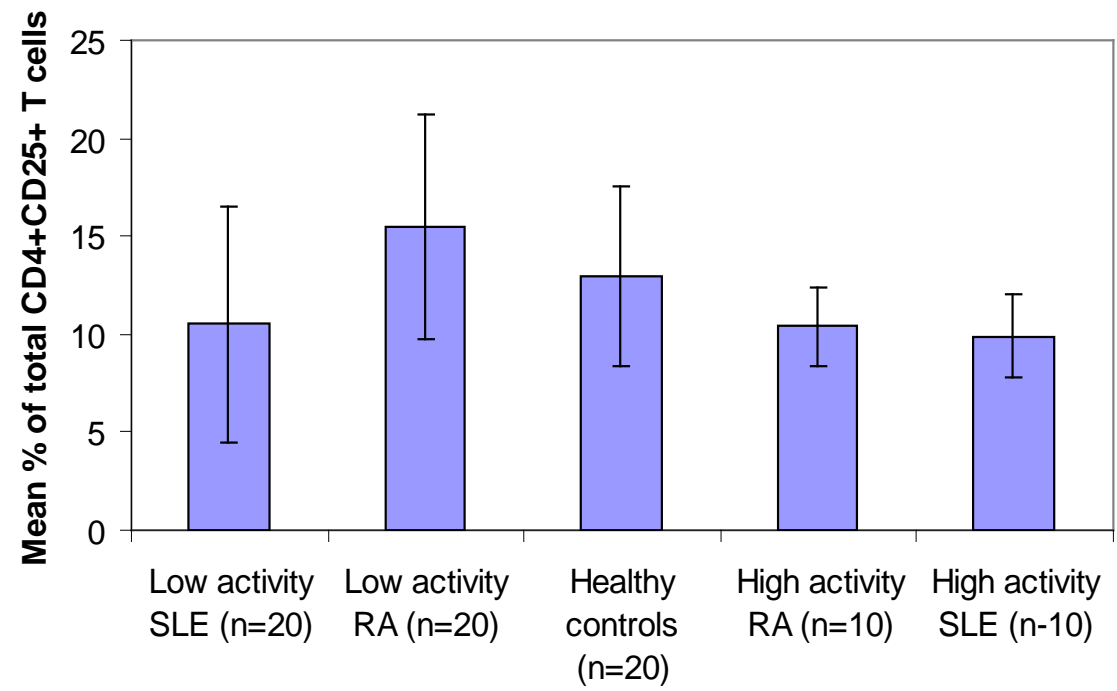

Fig. (1). Statistically insignificant decrease in the percentages of total CD4+ CD25+ T cells in peripheral blood (PB) from Systemic Lupus Erythematosus patients with low activity (SLEDAI=0-8), active SLE (SLEDAI >8) and rheumatoid arthritis (RA) patients with high activity (DAS score $\geq 5.4$ ) compared to healthy controls. A slight increase in CD4+ CD25+ T cells in PB of RA patients with low diseases activity (DAS score $<2.6$ ) was observed. Values are the mean \pm standard deviation (SD).

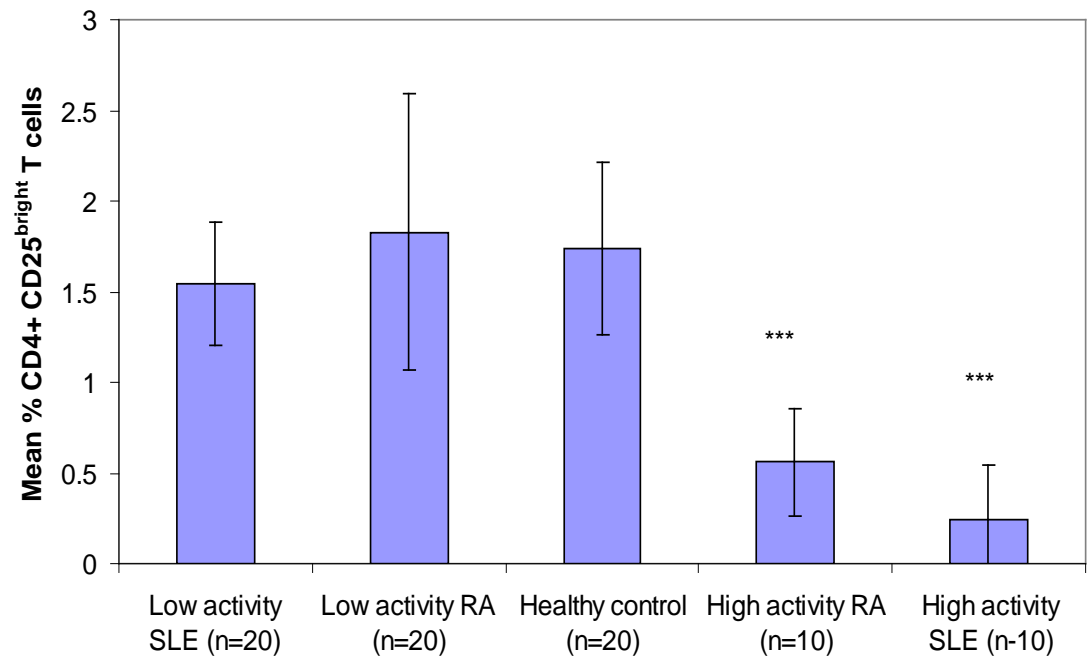

Fig. (2). Percentages of CD4+ CD25 $5^{\text {bright }} \mathrm{T}$ cells in each clinical group. Highly active Systemic Lupus Erythematosus (SLE, SLEDAI $>8$ points) and rheumatoid arthritis (RA, DAS $\geq 5.4$ ) patients exhibit a significant reduction ( $<0.001)$ in the CD4+ CD25 bright $T$ cells compared to patients with low activity or healthy control. (***= high significant differences). 


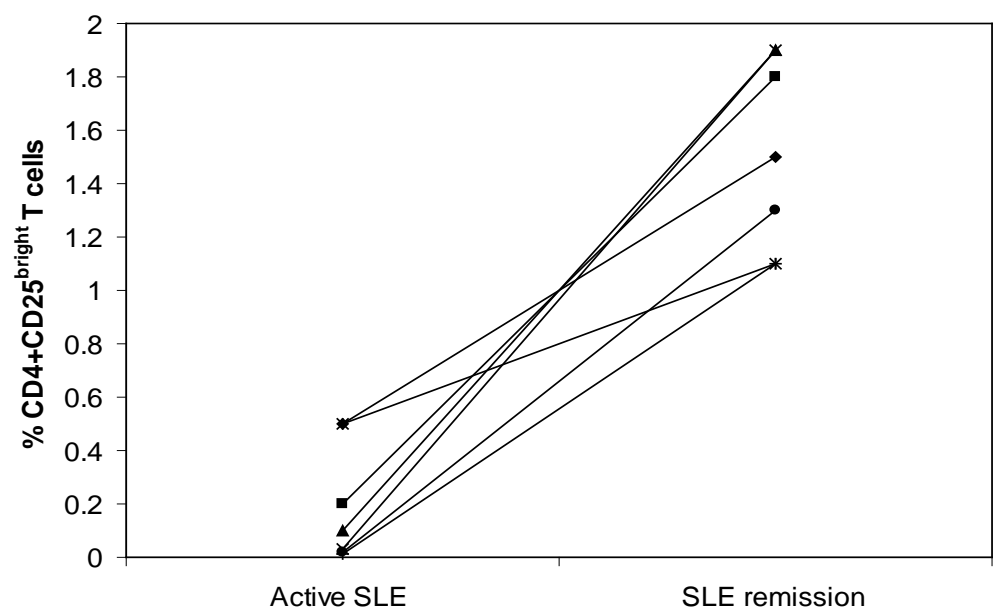

Fig. (3). The decreased number of CD4+CD25 bright $\mathrm{T}$ cells during disease activity was restored in remission period of seven patients with Systemic Lupus Erythematosus (SLE).

SLE group also showed low level of CD4+CD25 $5^{\text {bright }} \mathrm{T}$ cells but statistically insignificant. This probably a reflection of using low sample size $(n=20)$; larger sample size may offer a significant difference. The mean $( \pm \mathrm{SD})$ percentages of CD4+CD25 $5^{\text {bright }}$ as well as the total CD4+ CD25+ T cells are in line with the published "normal" values $[9,16,17]$.

CD4+CD25+ $\mathrm{T}$ cells have been investigated in several autoimmune diseases, presenting conflicting results in most cases [14-22]. These discrepancies may be attributed to the differences in the selection of patients (active or inactive diseases) or probably due to technical difficulties in CD4+ $\mathrm{CD} 25+\mathrm{T}$ cells phenotypic characterization. Because CD25 is transiently up-regulated in $\mathrm{T}$ cells after activation, circulating CD4+CD25+ $\mathrm{T}$ cells make a heterogeneous population [27]. Furthermore, patients treated with corticosteroids, alone or with other immunosuppressive drugs, had a significantly higher level of CD4+CD25+ than the group of patients not on corticosteroids treatment and the control group [14]. Our groups of patients were all in immunosuppressive drugs including corticosteroid. We did not correlate the type of medications given to patients with levels of regulatory $\mathrm{T}$ cells, because our aim was to correlate the diseases activity with levels of regulatory $\mathrm{T}$ cells.

The exact mechanisms that reduce the level of CD4+ CD25+ T cells in SLE patient are not clear. However, the following hypotheses have been suggested: Cytokine profile in SLE or RA patients may have a suppressive function towards those cells (e.g. TNF- $\alpha$ ) [11]. Moreover, patients with autoimmune diseases may release lymphocytes-specific cytotoxic antibodies [28].

It has been previously shown that only those cells expressing high levels of CD25 (CD25 $5^{\text {bright }}$ ) efficiently suppress proliferative responses, thus being considered true regulatory T cells [9]. However, FOXP3 (a forkhead/winged helix family member) has been shown to play an important role in controlling the development and functions of regulatory T cells [29]. In humans, FOXP3 is predominantly expressed in CD4+CD25+ cells, especially in the CD4+ CD25 $5^{\text {bright }}$ cells with regulatory functions [32-34]. Therefore, FOXP3 appears to be a specific marker for regulatory $\mathrm{T}$ cells and can be a potential therapeutic target for autoimmune diseases [30-32]. Hence, both of these markers (CD25, FOXP3) should be used for quantification of regulatory $\mathrm{T}$ cells in health and disease.

The use of regulatory $\mathrm{T}$ cells for the re-establishment of the peripheral tolerance is a novel approach for the treatment of autoimmune diseases. Administration of regulatory T cells may be one way to achieve this goal [33]. However, regulatory $\mathrm{T}$ cells are difficult to expand in vitro and evidences from animal models that polyclonal regulatory $\mathrm{T}$ cells can treat autoimmune diseases are still controversial. For example, adoptive transfer of CD4+ CD25+ regulatory T cells has been shown to cure murine colitis after disease onset in SCID mice [34]. Nevertheless, such transfer of these regulatory $\mathrm{T}$ cells has failed in experimental diabetes [35] and arthritis [36]. It is certainly, too early to speculate whether and how cellular therapy with regulatory $\mathrm{T}$ cells have therapeutic potential in autoimmune diseases until we have reliable knowledge about the function of these cells in diseases.

In summary, this work suggests that Omani patients with highly active SLE or RA exhibit a significant reduction in the $\mathrm{CD} 4+\mathrm{CD} 25^{\text {bright }}$ regulatory $\mathrm{T}$ cells subset, corresponding to data reported previously with different ethnic group. This significant defect in regulatory $\mathrm{T}$ cells not presents during disease remission. This data provides further evidence supporting the hypothesis of defect of regulatory T cells in SLE and RA patients; and may have an important implication in the context of the control of the inflammation and development of autoimmunity.

\section{ACKNOWLEDGEMENTS}

We thank Drs. Crystal Koh and Nasser Al-Nazwani for their excellent editorial assistance and critical reading of the manuscript.

\section{REFERENCES}

[1] Van Parijs L, Abbas AK. Homeostasis and self-tolerance in the immune system: turning lymphocytes off. Science 1998; 280: 2438

[2] Lan RY, Ansari AA, Lian ZX, Gershwin ME. Regulatory T cells: development, function and role in autoimmunity. Autoimmun Rev 2005; 4: 351-63. 
[3] Cohen PL. T- and B-cell abnormalities in systemic lupus. J Invest Dermatol 1993; 100: 69S-72S.

[4] Mills JA. Systemic lupus erythematosus. N Eng J Med 1994; 330: 1871-9

[5] Feldmann M, Brennan FM, Maini RN. Rheumatoid arthritis. Cell 1996; 85: 307-10.

[6] Maini RN, Feldmann M. Cytokine therapy in rheumatoid arthritis. Lancet 1996; 348: 824-35.

[7] Mauri C, Williams RO, Walmsley M, Feldmann M. Relationship between Th1/Th2 cytokine patterns and the arthritogenic response in collagen-induced arthritis. Eur J Immunol 1996; 26: 1511-8.

[8] Sakaguchi S, Sakaguchi N, Asano M, Itoh M, Toda M. Immunologic self-tolerance maintained by activated $\mathrm{T}$ cells expressing IL-2 receptor alpha-chains (CD25). Breakdown of a single mechanism of self-tolerance causes various autoimmune diseases. J Immunol 1995; 155: 1151-64.

[9] Baecher-Allan C, Brown JA, Freeman GJ, Hafler DA. CD4+ CD25high regulatory cells in human peripheral blood. J Immunol 2001; 167: 1245-53.

[10] Foussat A, Cottrez F, Brun V, Fournier N, Breittmayer JP, Groux $\mathrm{H}$. A comparative study between $\mathrm{T}$ regulatory type 1 and $\mathrm{CD} 4+\mathrm{CD} 25+\mathrm{T}$ cells in the control of inflammation. J Immunol 2003; 171: 5018-26.

[11] Valencia X, Yarboro C, Illei G, Lipsky PE. Deficient CD4+ CD25high $T$ regulatory cell function in patients with active systemic lupus erythematosus. J Immunol 2007; 178: 2579-88.

[12] Taams LS, Palmer DB, Akbar AN, Robinson DS, Brown Z, Hawrylowicz CM. Regulatory T cells in human disease and their potential for therapeutic manipulation. Immunology 2006; 118: 19.

[13] Graça L, Silva-Santos B, Coutinho A. The blind-spot of regulatory T cells. Eur J Immunol 2006; 36: 802-5.

[14] Azab NA, Bassyouni IH, Emad Y, Abd El-Wahab GA, Hamdy G, Mashahit MA. CD4+CD25+ regulatory T cells (TREG) in systemic lupus erythematosus (SLE) patients: the possible influence of treatment with corticosteroids. Clin Immunol 2008; 127: 151-7.

[15] Suárez A, López P, Gómez J, Gutiérrez C. Enrichment of CD4+CD25 high T cell population in SLE patients treated with glucocorticoids, Ann Rheum Dis 2006; 65: 1512-7.

[16] Crispin JC, Martinez A, Alcocer-Varela J. Quantification of regulatory $\mathrm{T}$ cells in patients with systemic lupus erythematosus. $\mathrm{J}$ Autoimmun 2003; 21: 273-6.

[17] Liu M-F, Wang C-R, Fung L-L, Wu C-R. Decreased CD4+CD25+ $\mathrm{T}$ cells in peripheral Blood of patients with systemic lupus erythematosus. Scan J Immunol 2004; 59: 198-202.

[18] Lawson CA, Brown AK, Bejarano V, et al. Early rheumatoid arthritis is associated with a deficit in the CD4+CD25high regulatory $\mathrm{T}$ cell population in peripheral blood. Rheumatology (Oxford) 2006; 45: 1210-7.

[19] Minami R, Sakai K, Miyamura T, Yamamoto M, Suematsu E. The role of $\mathrm{CD} 4(+) \mathrm{CD} 25(+)$ regulatory $\mathrm{T}$ cells in patients with rheumatoid arthritis, Nihon Rinsho Meneki Gakkai Kaishi 2006; 29: 3742.

[20] Kleer IM, Wedderburn LR, Taams LS, et al. CD4+CD25bright regulatory $\mathrm{T}$ cells actively regulate inflammation in the joints of pa- tients with the remitting form of juvenile idiopathic arthritis. J Immunol 2004; 172: 6435-43.

[21] Jiao Z, Wang W, Jia R, et al. Accumulation of FoxP3-expressing $\mathrm{CD} 4+\mathrm{CD} 25+\mathrm{T}$ cells with distinct chemokine receptors in synovial fluid of patients with active rheumatoid arthritis. Scand J Rheumatol 2007; 36: 428-33.

[22] Amelsfort JM, Jacobs KM, Bijlsma JW, Lafeber FP, Taams LS. CD4+CD25+ regulatory $\mathrm{T}$ cells in rheumatoid arthritis: differences in the presence, phenotype, and function between peripheral blood and synovial fluid. Arthritis Rheum 2004; 50: 2775-85.

[23] Tan EM, Cohen AS, Fries JF, et al. The 1982 revised criteria for the classification of systemic lupus erythematosus. Arthritis Rheum 1982; 25: 1271-7.

[24] Arnett FC, Edworthy SM, Bloch DA, et al. The American Rheumatism Association 1987 revised criteria for the classification of rheumatoid arthritis. Arthritis Rheum 1988; 31: 315-24.

[25] Bombardier C, Gladman DD, Urowitz MB, Caron D, Chang CH. Derivation of the SLEDAI. A disease activity index for lupus patients. The Committee on Prognosis Studies in SLE. Arthritis Rheum 1992; 35: 630-40.

[26] Gülfe A, Geborek P, Saxne T. Response criteria for rheumatoid arthritis in clinical practice: how useful are they. Ann Rheum Dis 2005; 64: 1186-9.

[27] Shahabuddin S. Expression of IL-2 receptor subunit p55 (CD25) on normal human lymphocytes. Clin Immunol Immunopathol 1993; 69: 175-9.

[28] Baráth S, Soltész P, Kiss E, et al. The severity of systemic lupus erythematosus negatively correlates with the increasing number of CD4+CD25(high)FoxP3+ regulatory $\mathrm{T}$ cells during repeated plasmapheresis treatments of patients. Autoimmunity 2007; 40: 521-8.

[29] Ziegler SF. FOXP3 of mice and men. Annu Rev Immunol 2006; 24: 209-26.

[30] Schubert LA, Jeffery E, Zhang Y, Ramsdell F, Ziegler SF. Scurfin (FOXP3) acts as a repressor of transcription and regulates $\mathrm{T}$ cell activation. J Biol Chem 2001; 276: 37672-9.

[31] Hori S, Nomura T, Sakaguchi S. Control of regulatory T cell development by the transcription factor Foxp3. Science 2003; 299: 1057-61.

[32] Lin SC, Chen KH, Lin CH, Kuo CC, Ling QD, Chan CH. The quantitative analysis of peripheral blood FOXP3-expressing T cells in systemic lupus erythematosus and rheumatoid arthritis patients. Eur J Clin Invest 2007; 37: 987-96.

[33] Frey O, Bräuer R. Regulatory T cells: magic bullets for immunotherapy? Arch Immunol Ther Exp (Warsz) 2006; 54: 33-43.

[34] Mottet C, Uhlig HH, Powrie F. Cutting edge: cure of colitis by CD4+CD25+ regulatory T cells. J Immunol 2003; 170: 3939-43.

[35] Bluestone JA, Tang Q, Sedwick CE. T regulatory cells in autoimmune diabetes: past challenges, future prospects. J Clin Immunol 2008; 28: 677-84.

[36] Frey O, Petrow PK, Gajda M, et al. The role of regulatory T cells in antigen-induced arthritis: aggravation of arthritis after depletion and amelioration after transfer of $\mathrm{CD} 4+\mathrm{CD} 25+\mathrm{T}$ cells. Arthritis Res Ther 2005; 7: R291-301. 